\title{
Neurogenesis following Stroke Affecting the Adult Brain
}

\author{
Olle Lindvall and Zaal Kokaia \\ Laboratory of Stem Cells and Restorative Neurology, Lund Stem Cell Center, University Hospital, \\ SE-221 84 Lund, Sweden \\ Correspondence: olle.lindvall@med.lu.se
}

\begin{abstract}
A bulk of experimental evidence supports the idea that the stroke-damaged adult brain makes an attempt to repair itself by producing new neurons also in areas where neurogenesis does not normally occur (e.g., the striatum and cerebral cortex). Knowledge about mechanisms regulating the different steps of neurogenesis after stroke is rapidly increasing but still incomplete. The functional consequences of stroke-induced neurogenesis and the level of integration of the new neurons into existing neural circuitries are poorly understood. To have a substantial impact on the recovery after stroke, this potential mechanism for self-repair needs to be enhanced, primarily by increasing the survival and differentiation of the generated neuroblasts. Moreover, for efficient repair, optimization of neurogenesis most likely needs to be combined with promotion of other endogenous neuroregenerative responses (e.g., protection and sprouting of remaining mature neurons, transplantation of neural stem/progenitor cells [NSPC]-derived neurons and glia cells, and modulation of inflammation).
\end{abstract}

Ctroke is caused by occlusion of a cerebral Sartery, which gives rise to focal ischemia with irreversible injury in a core region and partially reversible damage in the surrounding penumbra zone. In another type of insult, abrupt and near-total interruption of cerebral blood flow as a consequence of cardiac arrest or coronary artery occlusion leads to global ischemia and selective death of certain vulnerable neuronal populations, such as the pyramidal neurons of hippocampal CA1. During the last decade, these ischemic insults have been reported to induce the formation of new neurons in the adult rodent brain from neural stem/progenitor cells (NSPCs) located in two regions: the subventricular zone (SVZ), lining the lateral ventricle, and the subgranular zone (SGZ) in the dentate gyrus. Ischemia-induced neurogenesis is triggered both in areas where new neurons are normally formed, such as the dentate gyrus, and in areas that are nonneurogenic in the intact brain (e.g., the striatum).

In this review, we will summarize the current status of research on neurogenesis after stroke. We will also discuss the basic scientific problems that need to be addressed before this potential self-repair mechanism should be considered in a clinical-therapeutic perspective. Stroke is a leading cause of chronic disability in humans. No effective treatment to promote recovery in patients exists. Many different types of neurons and glial cells die in stroke. To repair

Editors: Fred H. Gage, Gerd Kempermann, and Hongjun Song

Additional Perspectives on Neurogenesis available at www.cshperspectives.org

Copyright (C) 2015 Cold Spring Harbor Laboratory Press; all rights reserved; doi: 10.1101/cshperspect.a019034

Cite this article as Cold Spring Harb Perspect Biol 2015;7:a019034 
the stroke-damaged brain may, therefore, seem unrealistic. However, even reestablishment of only a fraction of damaged neuronal circuitries could have important clinical implications. Here we will focus on the stroke-induced formation of new neurons in damaged areas where neurogenic mechanisms do not normally operate. The modulation of neurogenesis in the dentate gyrus by focal ischemic stroke will not be covered here.

\section{ANIMAL MODELS OF STROKE}

Experimental models, which mimic the conditions during ischemic stroke in humans, have been developed in animals. These models cause motor, sensory, and cognitive deficits similar to what is observed in stroke patients, and studies in postmortem specimens confirm the relevance of the animal models for the human condition (Leifer and Kowall 1993). In the most common model for neurogenesis research, stroke is induced by transient middle cerebral artery occlusion (MCAO) in rats and mice, which is accomplished by insertion of a filament through the internal carotid artery to the origin of the middle cerebral artery (MCA). Recirculation is restored by withdrawal of the filament. Depending on the duration of the occlusion, either only the dorsolateral part of the rat striatum will be damaged (30 min MCAO in rats) or the lesion will extend into the overlying parietal cortex ( $2 \mathrm{~h} \mathrm{MCAO})$. In another model of ischemic stroke, the MCA of spontaneously hypertensive rats is ligated with a thread distal to the origin of the striatal branches. In normal rats, the same procedure is combined with bilateral occlusion of the carotid arteries during about $1 \mathrm{~h}$. Both methods lead to selective ischemic lesions of the cerebral cortex without damage to the striatum.

Also, other animal models of stroke are being used to study neurogenesis. Subjecting exposed crania of rats to light beam with simultaneous systemic infusion of photosensitizer induces photothrombotic stroke with regionat-risk cortical tissue ( $\mathrm{Gu}$ et al. 1999; Keiner et al. 2009). Wiping the pia and attached blood vessels from the cortical surface causes perma- nent devascularization and damage to the cerebral cortex (Gonzalez and Kolb 2003). Embolic ischemic lesions to the striatum and cerebral cortex are induced by placing a blood clot at the origin of the MCA (Zhang et al. 1997).

\section{OCCURRENCE OF NEUROGENESIS IN ADULT RODENT STRIATUM AND CEREBRAL CORTEX AFTER STROKE}

The most solid evidence for stroke-induced neurogenesis in areas of the adult brain where new neurons are not normally formed has been obtained in the striatum (Fig. 1A). The initial findings were, first, that cells coexpressing the thymidine analog BrdU, given intraperitoneally after stroke, and markers of immature (e.g., doublecortin [DCX], PSA-NCAM, Hu) and mature neurons (e.g., NeuN and DARPP-32) are detected in the damaged striatum (Arvidsson et al. 2002; Parent et al. 2002). After BrdU injections, given early or late after the insult, the colabeled cells are first DCX immunoreactive over $2-3$ wk but then gradually lose this expression and become labeled with NeuN, consistent with a maturation process (Thored et al. 2006). Second, cells expressing neuroblast markers, such as DCX, are detected in the stroke-damaged striatum and coexpress transcription factors specific for developing striatal projection neurons (i.e., $\mathrm{Pbx}$ and Meis2) (Arvidsson et al. 2002). Third, injection of Cre-encoding plasmid into the lateral ventricles of transgenic mice carrying a floxed green fluorescent protein (GFP) gene, specifically labeling SVZ cells and their progeny, gives rise to GFP-labeled cells in the striatum coexpressing NeuN and having a mature neuronal morphology at $90 \mathrm{~d}$ after stroke (Yamashita et al. 2006). As described in detail below, a bulk of experimental data has now established that NSPCs in the SVZ give rise to neuroblasts, which migrate into the injured striatum and differentiate to mature neurons.

Recent evidence indicates that stroke, in addition to triggering striatal neurogenesis from NSPCs in SVZ, can also elicit a latent neurogenic program in striatal astrocytes in mice (Magnusson et al. 2014). Stroke was induced by MCAO, giving rise to a lesion primarily in 


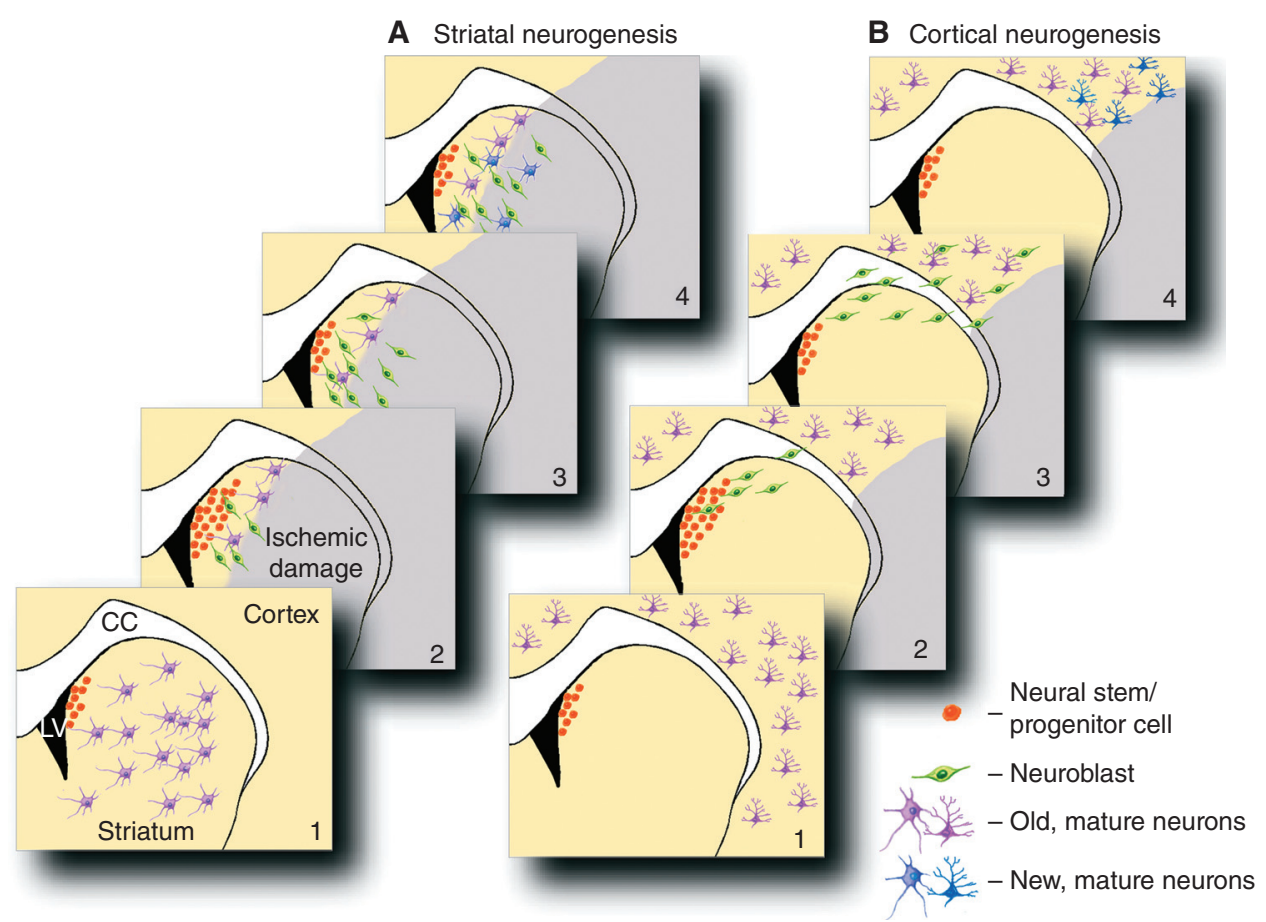

Figure 1. Schematic representation of stroke-induced neurogenesis in the striatum and cerebral cortex. $(A)$ Neural stem or progenitor cells reside in the subventricular zone (SVZ) adjacent to the lateral ventricle (1). Focal ischemic insults, which lead to pronounced loss of striatal and cortical neurons, give rise to increased proliferation of progenitors (2). Neuroblasts formed after and also, to some extent, before the stroke migrate to the damaged part of the striatum (3), where they differentiate and express markers specific for mature striatal projection neurons (4). The migration of neuroblasts and formation of new neurons continues for $1 \mathrm{yr}$ after the insult. (B) Focal ischemia-induced damage to the cortex triggers proliferation of SVZ progenitors (2). Neuroblasts migrate toward the cortical damage (3), and in the peri-infarct area start to express markers of mature neurons (4). Some experimental evidence suggests that, following stroke affecting the cerebral cortex, neurons are also produced from local cortical progenitors.

the striatum. Using genetic methods for fate mapping, astrocytes in this area were found to form immature neurons, which differentiated to mature neurons. In the healthy brain, Notch1 signaling was inhibiting the neurogenic program and prevented the astrocytes from generating neurons. Following a stroke, Notch1 signaling was suppressed and astrocytes could enter the neurogenic program. It remains to be shown whether the neurons derived from astrocytes are functional and to what extent they contribute to the spontaneous recovery after stroke.

The occurrence of neurogenesis in the cerebral cortex following stroke is less well established. In the initial studies describing strokeinduced striatal neurogenesis, no significant numbers of new neurons in the ischemic cerebral cortex were detected (Zhang et al. 2001; Arvidsson et al. 2002; Parent et al. 2002). However, it seems that under certain circumstances, limited accumulation of new neurons may occur in the cerebral cortex after stroke (Fig. 1B). Several other studies have described the presence of new cells expressing markers of neuroblasts or mature neurons in the ischemia-damaged cerebral cortex (Jiang et al. 2001; Zhang et al. 2006a; Ziv et al. 2007). It has also been shown that cortical neurogenesis after stroke can be triggered (Kolb et al. 2007) or enhanced (Jiang et al. 2001; Taguchi et al. 2004; Zhang et al. 2006a; Wang et al. 2007; Ziv et al. 2007) by additional manipulation (e.g., growth factor infusion). Leker and 
coworkers (2007) reported cortical neurogenesis in the distal MCAO model, which causes selective cortical damage. When BrdU was injected during days $1-5$ after the insult, the majority of $\mathrm{BrdU}^{+}$cells in the peri-infarct cortex at $1 \mathrm{wk}$ were expressing markers for NSPCs, such as Sox 2 and nestin. However, at 3 mo after the stroke, $\sim 12 \%$ of $\mathrm{BrdU}^{+}$cells were also $\mathrm{NeuN}^{+}$, indicating maturation, at least partly, of NSPCs into neurons.

Do new cortical neurons generated after stroke originate in the SVZ? Jin and coworkers (Jin et al. 2003) reported migration of DCX ${ }^{+}$ neuroblasts from SVZ to the boundaries of the cortical lesion. However, whether these neuroblasts were formed in response to the ischemic insult was unclear (Jin et al. 2003). Following photothrombotic cortical stroke in mice, $\mathrm{DCX}^{+}$ cells, presumably neuroblasts, seemed to migrate during $1 \mathrm{yr}$ from the SVZ within the corpus callosum to the lesion site but no mature neurons were formed (Osman et al. 2011). Another study (Kreuzberg et al. 2010) using transgenic mice, in which neuroblasts originating in SVZ expressed GFP, reported that neural progenitors migrated toward the cortical infarct after MCAO. Here they differentiated to mature neurons expressing the interneuron marker calretinin. Similarly, Saha et al. (2013) found that following aspiration of motor cortex in mice, neuroblasts originating in SVZ, transduced with a GFP-expressing lentiviral vector, migrated to the injured cortical tissue and differentiated to glial cells and, to a much lesser extent, mature neurons.

Cortical neurogenesis has also been reported in rats after transient global forebrain ischemia induced by bilateral common carotid artery occlusion (Ohira et al. 2010). Following the insult, progenitors located in the subpial region of the neocortex (layer 1) proliferated and then migrated into deeper cortical layers where they differentiated to GABAergic interneurons. Analysis of c-Fos expression after exposure to an enriched environment indicated that the new neurons were incorporated into cortical circuitry.

The larger variability in the magnitude of cortical as compared to striatal neurogenesis in different studies could be related to the stroke model used, the pattern, location, extent and dynamics of the ischemic lesion, and the resulting differences in the cues responsible for migration and neuronal differentiation of the new cells. It is also important to emphasize that to firmly establish the occurrence of neurogenesis in different brain areas, especially in a pathological environment, a combination of currently available molecular and genetic approaches and their vigorous use are crucial (Breunig et al. 2007).

\section{EVIDENCE FOR A NEUROGENIC RESPONSE AFTER STROKE IN HUMANS}

The SVZ has been identified as the main source of neuroblasts that are generated after stroke and migrate toward the damaged area in rodents. It is well established also that the adult human brain contains NSPCs in the SVZ (Eriksson et al. 1998; Bernier et al. 2000; Sanai et al. 2004). However, whether neuroblasts from SVZ migrate through the rostral migratory stream to the olfactory bulb in adult humans similar to rodents (Curtis et al. 2007) or migration stops at 18 mo after birth (Sanai et al. 2011) is controversial. Although it seems possible that SVZ in humans has a latent potential for producing new neurons for repair, the evidence for neurogenesis in the brain of stroke patients is so far limited. Suggesting a neurogenic response, Macas et al. (2006) found increased number of cells expressing the proliferation marker Ki67 in the ipsilateral SVZ, and of neural progenitor cells in the parenchyma close to the ventricular wall. Clear signs of increased proliferative activity and numbers of neural progenitors in the ipsilateral SVZ were detected in a group of aged patients who died during the first $2 \mathrm{wk}$ after stroke (Marti-Fabregas et al. 2010).

Some preliminary evidence suggests increased neurogenic activity in the human brain after stroke also in areas remote from SVZ in the ischemic penumbra surrounding cortical infarcts. The presumed new cells expressing neuronal markers, such as DCX, were preferentially localized in the vicinity of blood vessels (Jin et al. 2006). Minger et al. (2007) reported cells from an aged patient that expressed markers of 
NSPCs both around and distant from the infarcted area as well as an increased number of NSPCs in the neurogenic region of the lateral ventricular wall. Finally, Nakayama et al. (2010) observed cells expressing nestin and musashi-1, markers associated with NSPCs, in the ischemic cerebral cortex of humans during the first month after embolic stroke, suggesting a regenerative response.

Whether stroke-induced neurogenesis is significant in the human cerebral cortex was addressed by measuring the level of ${ }^{14} \mathrm{C}$ for birth dating as has been done in healthy individuals and show an occurrence of hippocampal (Spalding et al. 2013) but an absence of cortical neurogenesis (Bhardwaj et al. 2006). However, although Huttner et al. (2014) found evidence for DNA fragmentation and repair in neurons in the penumbra after stroke, the patients' genomic DNA had a ${ }^{14} \mathrm{C}$ concentration corresponding to the time of birth of the individual. Thus, significant numbers of neurons are not regenerated in the adult human neocortex following stroke. Consistent with this finding, stroke-generated $\mathrm{DCX}^{+} / \mathrm{BrdU}^{+}$cells migrating along the corpus callosum to the peri-infarct cortex were detected at $2 \mathrm{wk}$ after distal MCAO in mice (Huttner et al. 2014). At $4 \mathrm{wk}$, no $\mathrm{NeuN}^{+} /$ $\mathrm{BrdU}^{+}$cells were found in the peri-infarct cortex. Thus, the new $\mathrm{DCX}^{+}$, presumed neuroblasts, observed in the peri-infarct cortex in the 2-wk group, had died after $4 \mathrm{wk}$ and had not differentiated to mature neurons. Moreover, some studies in rats (Arvidsson et al. 2002; Parent et al. 2002) failed to detect significant numbers of new neurons in the injured cerebral cortex following MCAO despite the occurrence of robust stroke-induced striatal neurogenesis from NSPCs in SVZ. It remains to be analyzed, using the ${ }^{14} \mathrm{C}$ method for birth dating, whether the increased cell proliferation in SVZ after stroke also leads to striatal neurogenesis in humans. Interestingly, in a consecutive series of stroke cases, Delavaran et al. (2013) found that $\sim 50 \%$ of patients had infarcts close to $(\leq 2 \mathrm{~mm})$ the SVZ, which may trigger a neurogenic response. The lack of neurogenesis in the human neocortex following stroke indicates that neuronal replacement strategies to promote
Neurogenesis following Stroke in the Adult Brain

functional recovery in this structure will require intracortical implantation of neuronal precursors. Alternatively, in the future, this may be possible with recruitment of SVZ-derived neuroblasts or direct in vivo reprogramming and differentiation to cortical neurons.

\section{MECHANISMS INVOLVED IN STROKE- INDUCED NEUROGENESIS}

\section{Proliferation}

Overall, cell proliferation in the ipsilateral SVZ is increased 1 to 2 wk after MCAO (Jin et al. 2001; Arvidsson et al. 2002; Zhang et al. 2004a,b), but has returned to baseline at $6 \mathrm{wk}$ (Thored et al. 2006). However, the ipsilateral SVZ is expanded at 2, 6, and 16 wk after MCAO (Thored et al. 2006), and the number and size of neurospheres isolated from the ipsilateral SVZ are increased at $6 \mathrm{wk}$. Taken together, these findings provide evidence that stroke leads to long-term alterations in the stem-cell niche in the SVZ.

During embryonic development, the orientation of mitotic cleavage regulates neurogenesis. Zhang et al. (2004a) have shown that not only the number of mitotic cells increases but also the cleavage orientation in the SVZ changes from horizontal to vertical during the first week after stroke in the adult brain. Thus, stroke leads to a transient alteration in SVZ cell division from asymmetric to symmetric, thereby expanding the pool of progenitor cells. Stroke was also found to increase the proportion of dividing cells in the SVZ and reduce their cell-cycle length, largely as a result of a shortening of the $G_{1}$ phase (Zhang et al. 2006b). These actively proliferating cells were most likely progenitor cells.

Interestingly, Zhang et al. (2007a) found that the ependymal cells lining the lateral ventricular wall also proliferate acutely and transiently after stroke. The ependymal cells were transformed into radial glia cells, and were surrounded by type- $C$ (progenitors) and type-A (neuroblasts) cells in the SVZ. In mice, ependymal cells proliferated and gave rise to neuroblasts and astrocytes after stroke caused by suppression of Notch signaling (Carlen et al. 2009). None of the stroke-generated neuroblasts 
derived from ependymal cells survived to become mature neurons. Ependymal cells delaminated from the ependymal layer and did not self-renew (Carlen et al. 2009). Another study could not demonstrate proliferating ependymal cells, and the ependymal layer remained intact after stroke in mice (Young et al. 2013). Using long-term fate mapping of FoxJ1-expressing cells in lateral ventricular wall of adult rats (including ependymal cells and a subset of astrocytes) by in vivo electroporation combined with piggyBac transposon, Devaraju et al. (2013) found that these cells give rise to neuroblasts and mature neurons in the olfactory bulb both in intact and stroke-damaged brain. However, Devaraju et al. (2013) failed to detect any significant contribution of these cells to striatal neurogenesis after stroke.

Several molecular mechanisms are involved in regulating NSPC proliferation after stroke. MicroRNAs (miRNAs) are small noncoding RNA molecules that regulate gene expression. Recent experimental evidence indicates an important role of miRNAs in mediating strokeinduced neurogenesis, suggesting novel therapeutic targets for improving cellular repair. Stroke alters the expression of a number of miRNAs in SVZ NSPCs of adult rats (Liu et al. 2011), including a reduction of miR124a expression at $7 \mathrm{~d}$ after MCAO, concomitantly with a marked increase of NSPC proliferation. Interestingly, Liu et al. (2011) found that introduction of miR-124a inhibited ischemic NSPC proliferation and promoted neuronal differentiation in vitro by targeting Jagged1, a ligand of Notch. Members of the miR17-92 cluster of miRNAs are up-regulated in the SVZ NSPCs at $7 \mathrm{~d}$ after MCAO in adult rats and mice (Liu et al. 2011, 2013). Overexpression of the miR17-92 cluster in SVZ of ischemic animals increased, whereas inhibition of individual members of the miR17-92 cluster suppressed cell proliferation (Liu et al. 2013). Activation of the sonic hedgehog signaling pathway upregulated miR17-92 cluster expression.

Both Notch1 and the naturally occurring activator, Jagged1, are expressed in the adult SVZ (Stump et al. 2002). Reduced Jagged1/Notch1 signaling decreased SVZ cell proliferation in mice (Nyfeler et al. 2005). Conversely, administration of Notch ligands increased the number of proliferating cells in SVZ and new cells expressing the immature neuronal marker $\mathrm{Hu}$ in the cerebral cortex of intact rats (AndroutsellisTheotokis et al. 2006). Also following cortical stroke, supplying Notch ligands stimulated cell proliferation in SVZ (Androutsellis-Theotokis et al. 2006). Studies in neurosphere cultures derived from adult rats provided further evidence that the Notch signaling pathway mediates SVZ progenitor proliferation (Wang et al. 2009a). Finally, rats subjected to MCAO showed increased levels of Notch 1 and its downstream transcriptional targets, Hesl and sonic hedgehog, in SVZ at 4 and $24 \mathrm{~h}$ (Wang et al. 2009b). The stroke-induced cell proliferation in the SVZ was markedly attenuated by inhibition of the Notch1 signaling pathway. Taken together, these findings suggest that Notch ligands may be useful to enhance NSPC expansion during the recovery phase after stroke.

The adaptor protein LNK is an intrinsic negative regulator of hematopoietic stem-cell proliferation and expansion (Takaki et al. 2000; Buza-Vidas et al. 2006). Recently, Ahlenius et al. (2012) demonstrated that LNK is expressed in NSPCs in the adult rodent and human SVZ. Deletion of Lnk caused increased NSPC proliferation, whereas overexpression decreased mitotic activity of these cells in vitro. $\mathrm{Lnk}^{-/-}$ mice exhibited increased NSPC proliferation after stroke, but not in intact brain or following status epilepticus. Lnk expression after stroke increased in SVZ through the transcription factors STAT1/3. LNK attenuated insulin-like growth factor (IGF)-1 signaling by inhibition of AKT phosphorylation, resulting in reduced NSPC proliferation. These findings identify LNK as a stroke-specific endogenous negative regulator of NSPC proliferation in SVZ.

Tumor necrosis factor receptor 1 (TNFR-1) is another negative regulator of stroke-induced SVZ NSPC proliferation (Iosif et al. 2008). The increased cell proliferation at $1 \mathrm{wk}$ after stroke occurred concomitantly with elevated microglia numbers and TNF- $\alpha$ and TNFR-1 gene expression in SVZ of wild-type mice. TNFR-1 was expressed on sorted SVZ progenitor cells from 
nestin-GFP reporter mice. In animals lacking TNFR-1, stroke-induced SVZ cell proliferation and neuroblast formation were enhanced. In contrast, deletion of TNFR-1 did not alter basal or status epilepticus-stimulated cell proliferation in SVZ. Addition of TNF- $\alpha$ reduced size and numbers of SVZ neurospheres through a TNFR-1-dependent mechanism without affecting cell survival.

\section{Survival}

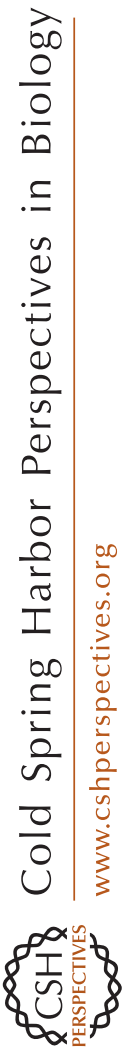

About $80 \%$ of the stroke-generated striatal neurons die during the first $2 \mathrm{wk}$ after their formation (Arvidsson et al. 2002). Caspases are probably involved in this neuronal loss, and administration of caspase inhibitors markedly promotes neuroblast survival in the damaged striatum (Thored et al. 2006). It is conceivable that the inflammatory changes accompanying the ischemic damage contribute to the poor survival of the new striatal neurons similar to what has been described for new hippocampal neurons in an inflammatory environment (Ekdahl et al. 2003; Monje et al. 2003). In agreement, Hoehn et al. (2005) found that administration of the nonsteroidal anti-inflammatory drug indomethacin increased the number of neuroblasts in the striatum after stroke. Also, Liu et al. (2007) reported that minocycline, administered during the 4 wk after transient MCAO in rats, reduced the number of activated microglia and increased the number of new, mature neurons in the dentate gyrus.

The role of inflammation for stroke-induced neurogenesis is, however, complex, and microglia can most likely also be beneficial (e.g., by producing factors that are important for migration of newly generated neuroblasts). Interestingly, Thored et al. (2009) showed that during the several months following stroke in rats, increased numbers of activated microglia are localized in the ipsilateral SVZ concomitant with the continuous production of new neuroblasts migrating into the striatum. The immune cells included both resident microglial cells and blood-borne central nervous system (CNS)-infiltrating macrophages. It is tempting to speculate that factors released from these microglia/ macrophages contribute to the maintenance of the neurogenic response. In line with this idea, this latter effect was, at least in part, attributed to the ability of a substantial proportion of these immune cells to express IGF-1 (Thored et al. 2009). Furthermore, chronically activated microglia are permissive to neuronal differentiation and survival in adult mouse SVZ cultures (Cacci et al. 2008), and microglia and microgliaconditioned media rescue the in vitro formation of neuroblasts from SVZ NSPCs, a property that is otherwise lost over the course of continued culture (Walton et al. 2006). Moreover, interleukin (IL)-15, which is expressed by NSPCs in SVZ and produced by activated microglia, has been reported to promote proliferation and self-renewal of SVZ NSPCs, maintaining them in an undifferentiated state (Gomez-Nicola et al. 2011). Finally, microglia activated by IL4 , which are reminiscent of alternatively activated macrophages, support neurogenesis (Butovsky et al. 2006).

In addition to innate immune cells, adaptive immune cells, in particular, T cells, are recruited within CNS injured areas, take part in the repair process, and might influence neurogenesis (Kokaia et al. 2012). Cytokines released by T-helper cells promote neurogenesis in vitro via direct effect on innate immune cells (Butovsky et al. 2006). Immune-deficient mice show impaired neurogenesis, whereas genetically modified CNS-specific T-helper cells promote hippocampal neurogenesis ( $\mathrm{Ziv}$ et al. 2006; Wolf et al. 2009), possibly through a remote mechanism. Under pathological conditions, the interaction between lymphocytes and NSPCs is even more complex. For example, lymphocytes have been reported to be important in the abortive neuroregenerative response following stroke confined to the cerebral cortex in mice. Immunodeficient mice and mice selectively depleted of $\mathrm{CD}^{+} \mathrm{T}$ lymphocytes exhibit reduced apoptosis and enhanced proliferation of NSPCs following cortical stroke (Saino et al. 2010). Activated $\mathrm{CD}^{+}{ }^{+} \mathrm{T}$ cells expressing glucocorticoidinduced TNFR have been reported to be responsible for the negative effect on NSPCs (Takata et al.2012). This complexity reflects the dynamics of the immune response following injury 
and, as a consequence, the continued changes in the need for the repair; the same immune cells can be helpful or harmful at different stages in the response to injury.

\section{Recruitment to Damaged Area}

The new neuroblasts exhibit distinct migratory behaviors and can divide on their way through the striatum toward the damage (Zhang et al. 2007b). Radial glia, which are distributed both in the SVZ and the ischemic striatum after stroke, are probably involved in guiding the migrating neuroblasts, as evidenced by both in vivo and in vitro data (Zhang et al. 2007a). There is also a close association between the newly formed neurons and the vasculature when they migrate toward the damaged area. At $18 \mathrm{~d}$ following $30 \mathrm{~min} \mathrm{MCAO}$ in mice, Yamashita et al. (2006) found chains of neuroblasts around endothelial cells, the neuroblasts being elongated parallel to the blood vessels and the chains oriented in the mediolateral direction. In another model, at $7 \mathrm{~d}$ after focal cortical stroke in mice (Ohab et al. 2006), neuroblasts were located in large numbers in physical proximity to endothelial cells in the peri-infarct cortex, where active vascular remodeling occurred. Thored et al. (2007) found that the newly formed neuroblasts were located in the vicinity of blood vessels throughout long-term neurogenesis (at least up to 16 wk after the insult). The majority of the neuroblasts migrated toward the ischemic damage through the striatal area, which, selectively, as compared to other striatal areas adjacent to SVZ, exhibited both a long-lasting increase of vessel density and, during the first $2 \mathrm{wk}$ after the insult, endothelial cell proliferation, consistent with angiogenesis. The blood vessels probably play a role both for migration and survival and differentiation of the closely located neuroblasts by endothelial release of factors, such as stromal cell-derived factor 1 (SDF-1) and brain-derived neurotrophic factor (BDNF) (Louissaint et al. 2002; Ohab et al. 2006; Wang et al. 2006).

The close association between GFP-labeled neural progenitor cells/neuroblasts and the vasculature, both in the early phase when the cells exit the SVZ and in the striatum, has been visualized in living slices of ischemic mouse brains using time-lapse imaging (Zhang et al. 2009; Kojima et al. 2010; Grade et al. 2013). Neuroblasts in the migrating chains were highly motile and extended or retracted their processes (Zhang et al. 2009). The interaction with blood vessels seemed to provide directional guidance for the progenitor cells (Kojima et al. 2010). The average speed of neuroblast migration in the ischemic striatum was estimated at $28.7 \pm$ 1.0 (Zhang et al. 2009) or $33.1 \pm 1.6 \mu \mathrm{m} / \mathrm{h}$ (Kojima et al. 2010) with images acquired every 15 or $30 \mathrm{~min}$, respectively. However, using images acquired every $30 \mathrm{sec}$ (Grade et al. 2013), it was possible to distinguish resting and migratory phases. Interestingly, compared to neuroblasts migrating in the rostral migratory stream, neuroblasts in the ischemic striatum spent more time in the resting state, whereas the speed of migration was similar (ipsilateral rostral migratory stream (RMS): $204.9 \pm 3.9 \mu \mathrm{m} / \mathrm{h}$; striatum: $192.0 \pm 7.3 \mu \mathrm{m} / \mathrm{h})$.

The molecular mechanisms involved in directing the new neurons to the damaged area are only partly understood. The most well established one regulating migration is the chemokine SDF-1 and its cognate receptor CXCR4. Following stroke, SDF-1 is expressed in reactive atrocytes and activated microglia in the damaged area, and SDF-1 levels are increased in the stroke hemisphere (Robin et al. 2005). CXCR4 is expressed on the neural progenitors and strokegenerated neuroblasts (Robin et al. 2006). When blocking CXCR4, the migration of neuroblasts was markedly attenuated (Robin et al. 2006; Thored et al. 2006). Taken together, these data indicate that SDF-1/CXCR4 signaling regulates the directed migration of new striatal neurons toward the ischemic damage. The occurrence of this mechanism is another example of how the inflammation, which is associated with stroke, is a major regulator of striatal neurogenesis.

Another factor of importance for neuroblast migration after stroke is monocyte chemoattractant protein-1 (MCP-1) (Yan et al. 2007). MCP-1 is up-regulated in activated microglia and reactive astrocytes in the cortex and striatum, and the new neuroblasts express the MCP-1 
receptor CCR2 after stroke. Arguing for involvement of this factor in the migration, transgenic mice lacking MCP-1 or CCR2 showed less recruitment of neuroblasts into the striatum after stroke (Yan et al. 2007). Similarly, osteopontin, which is up-regulated in microglia/macrophages following stroke, seems to promote neuroblast migration in ischemic striatum by acting on the integrin $\beta 1$ receptor on the progenitors themselves (Yan et al. 2009). Infusion of a neutralizing antibody against osteopontin into striatum markedly suppressed stroke-induced neuroblast migration in striatum.

An important question is how the newly formed neuroblasts can migrate through the ischemic and partially damaged striatum. Lee et al. (2006) reported that the extracellular protease matrix metalloproteinase 9 (MMP-9) is colocalized with the neuroblast marker DCX in the SVZ and striatum following stroke in mice. Administration of an MMP inhibitor markedly reduced neuroblast migration. These data indicate that extracellular proteolysis through the action of MMP is involved in neuroblast migration after stroke (Lee et al. 2006). Barkho et al. (2008) provided evidence that not only MMP-9 but also MMP-3 is expressed in migrating $\mathrm{DCX}^{+}$neuroblasts in a mouse stroke model. Using an in vitro assay system and specific small interfering (si)RNAs, endogenous MMP-3 and MMP-9 were found to promote chemokine-induced migration.

Erythropoietin (EPO) administered to the stroke-damaged brain promotes neurogenesis (Table 1). However, endogenous EPO also seems to be involved in the regulation of neurogenesis after stroke. Conditional knockdown of the EPO receptor in mice subjected to cortical stroke leads to reduced SVZ cell proliferation and impaired continued migration of neuroblasts to peri-infarct cortex (Tsai et al. 2006).

The extension of the damage plays an important role for the degree of recruitment of new neuroblasts to the striatum after stroke. Following $30 \mathrm{~min} \mathrm{MCAO}$, which gave rise to a lesion restricted to the striatum, the number of new striatal neuroblasts was markedly fewer as compared to a $2 \mathrm{~h}$ insult, which caused more extensive striatal damage and, in addition, inju- ry to the overlying parietal cortex (Thored et al. 2006). The number of neuroblasts correlated significantly to the volume of striatal injury. Thus, the extent of the ischemic lesion influences the degree of activation of the molecular and cellular mechanisms that promote recruitment of new striatal neurons after stroke.

Stroke mainly affects older people and it is, therefore, of major clinical importance whether new neurons can also be recruited to the ischemically damaged area in the aged brain. No differences between young ( $3 \mathrm{mo}$ ) and old (15 mo) rats were observed in number and distributional pattern of new neuroblasts and mature neurons in the damaged striatum after stroke (Darsalia et al. 2005). Thus, the strokedamaged aged brain is also permissive for neuroblast migration, and this potential self-repair mechanism seems to operate similarly in young and old brains.

\section{Differentiation}

In most studies, NeuN or MAP-2 coexpression in BrdU-labeled cells has been taken as evidence for the formation of new mature neurons after stroke. Little is known about the specific phenotype of these neurons. Arvidsson et al. (2002) estimated that $42 \%$ of the mature, new $\mathrm{BrdU}^{+} /$ $\mathrm{NeuN}^{+}$neurons formed after stroke in the striatum expressed DARPP-32, which is a specific marker for striatal medium-sized spiny neurons. This is the phenotype of most of the neurons destroyed by the ischemic lesion. Similarly, Parent et al. (2002) reported that a majority of new neurons in the striatal peri-infarct area after stroke were DARPP- $32^{+}$. Hou et al (2008) reported that the stroke-induced striatal cells, labeled through retroviral transfection of SVZ cells, differentiated to GABAergic and cholinergic neurons. In another model of striatal injury (excitotoxic lesion), Collin et al. (2005) described the generation of cells expressing markers of interneurons (parvalbumin and neuropeptide Y). Such cells were not detected following MCAO in rats (Parent et al. 2002). In contrast, Teramoto et al. (2003) observed no $\mathrm{BrdU}^{+}$cells expressing DARPP-32 but a substantial number of $\mathrm{BrdU}^{+}$cells colabeled with 
O. Lindvall and Z. Kokaia

Table 1. Examples of treatments modulating neurogenesis following focal ischemic stroke

\begin{tabular}{|c|c|c|c|c|}
\hline Stroke model/duration & Species/strain & Treatment/compound & Effect & References \\
\hline $\mathrm{MCAO} / 2 \mathrm{~h}$ & Rat/Wistar & $\begin{array}{l}\text { Intraventricular } \\
\text { infusion/caspase } \\
\text { inhibitor }\end{array}$ & $\begin{array}{l}\text { Increased survival of } \\
\text { neuroblasts }\left(\mathrm{DCX}^{+}\right. \\
\left.\text {and } \mathrm{Dcx}^{+} / \mathrm{BrdU}^{+}\right) \text {in } \\
\text { striatum }\end{array}$ & $\begin{array}{c}\text { Thored et al. } \\
2006\end{array}$ \\
\hline $\mathrm{MCAO} / 2 \mathrm{~h}$ & Rat/Wistar & Infusion/GDNF & $\begin{array}{l}\text { Increased proliferation of } \\
\text { progenitors }\left(\mathrm{BrdU}^{+}\right. \\
\left.\text {and } \mathrm{Ki}^{+} \mathrm{7}^{+}\right) \text {in } \mathrm{SVZ} \text { and } \\
\text { neuroblasts }\left(\mathrm{DCX}^{+}\right) \text {in } \\
\text { striatum }\end{array}$ & $\begin{array}{l}\text { Kobayashi } \\
\text { et al. } 2006\end{array}$ \\
\hline $\mathrm{MCAO} / 30 \mathrm{~min}$ & Rat/Wistar & $\begin{array}{l}\text { Intranigral injection/ } \\
\text { rAAV-BDNF }\end{array}$ & $\begin{array}{l}\text { Increased number of } \\
\text { neuroblasts }\left(\mathrm{Dcx}^{+}\right) \text {in } \\
\text { striatum }\end{array}$ & $\begin{array}{l}\text { Gustafsson } \\
\text { et al. } 2003\end{array}$ \\
\hline $\mathrm{MCAO} / 2 \mathrm{~h}$ & $\begin{array}{l}\text { Rat/Sprague- } \\
\text { Dawley (SD) }\end{array}$ & Orally/indomethacin & $\begin{array}{l}\text { Increased number of } \\
\text { newborn }\left(\mathrm{BrdU}^{+}\right) \text {cells } \\
\text { coexpressing Dcx, } \\
\text { nestin, GFAP, or NG2 } \\
\text { in striatum and cortex }\end{array}$ & $\begin{array}{l}\text { Hoehn et al. } \\
2005\end{array}$ \\
\hline Embolic MCAO & Rat/Wistar & Orally/Tadalafil & $\begin{array}{l}\text { Increased number of } \\
\text { BrdU }^{+} \text {cells in SVZ }\end{array}$ & $\begin{array}{c}\text { Zhang et al. } \\
\text { 2006a }\end{array}$ \\
\hline $\mathrm{MCAO} / 20 \mathrm{~min}$ & $\begin{array}{l}\text { Mouse/129S6/ } \\
\text { SvEvTac }\end{array}$ & $\begin{array}{l}\text { Intraventricular } \\
\text { infusion/EGF }\end{array}$ & $\begin{array}{l}\text { Increased number of } \\
\text { neuroblasts }\left(\mathrm{DCX}^{+}\right) \\
\text {and newborn neurons } \\
\left(\mathrm{BrdU}^{+} / \mathrm{NeuN}^{+}\right) \text {in } \\
\text { striatum }\end{array}$ & $\begin{array}{l}\text { Teramoto } \\
\text { et al. } 2003\end{array}$ \\
\hline Embolic MCAO & Rat/Wistar & Intraperitoneally/EPO & $\begin{array}{l}\text { Increased number of } \\
\mathrm{BrdU}^{+}, \text {nestin }^{+} \text {and } \\
\mathrm{DCX}^{+} \text {cells in SVZ }\end{array}$ & $\begin{array}{l}\text { Wang et al. } \\
2004\end{array}$ \\
\hline Distal MCAO & $\begin{array}{l}\text { Transgenic } \\
\text { mice/C57B/6 }\end{array}$ & $\begin{array}{l}\text { Conditional brain- } \\
\text { specific EPO receptor } \\
\text { knock out }\end{array}$ & $\begin{array}{l}\text { Decreased number of } \\
\text { proliferating }\left(\text { BrdU }^{+}\right) \\
\text {cells in SVZ; decreased } \\
\text { number of neuroblasts } \\
\left(\mathrm{DCX}^{+}\right) \text {in cortex } \\
\text { (impaired migration) }\end{array}$ & $\begin{array}{l}\text { Tsai et al. } \\
2006\end{array}$ \\
\hline $\begin{array}{l}\text { Devascularization } \\
\text { stroke }\end{array}$ & $\begin{array}{l}\text { Rat/Long- } \\
\text { Evans }\end{array}$ & $\begin{array}{l}\text { Intraventricular } \\
\text { infusion/EGF + EPO }\end{array}$ & $\begin{array}{l}\text { Increased cell migration } \\
\text { ( } \beta \text {-gal-labeled) from } \\
\text { SVZ to cortex }\end{array}$ & $\begin{array}{l}\text { Kolb et al. } \\
\quad 2006\end{array}$ \\
\hline $\mathrm{MCAO} / 90 \mathrm{~min}$ & Rat/SD & $\begin{array}{l}\text { Intraventricular } \\
\text { infusion/HB-EGF }\end{array}$ & $\begin{array}{l}\text { Increased proliferation } \\
\left(\mathrm{BrdU}^{+}\right) \text {in } \mathrm{SVZ} ; \\
\text { decreased migration of } \\
\text { neuroblasts }\left(\mathrm{DCX}^{+}\right) \text {in } \\
\text { striatum }\end{array}$ & $\begin{array}{c}\text { Jin et al. } \\
2004\end{array}$ \\
\hline $\begin{array}{l}\text { Embolic MCAO/ } \\
\text { permanent }\end{array}$ & Rat/Wistar & Orally/Sildenafil & $\begin{array}{l}\text { Increased number of } \\
\text { proliferating }\left(\mathrm{BrdU}^{+}\right) \\
\text {in SVZ; increased } \\
\text { number of neuroblasts } \\
\left(\mathrm{Tuj}-1^{+}\right) \text {in the SVZ } \\
\text { and striatum }\end{array}$ & $\begin{array}{l}\text { Zhang et al. } \\
2002\end{array}$ \\
\hline
\end{tabular}


Neurogenesis following Stroke in the Adult Brain

Table 1. Continued

\begin{tabular}{|c|c|c|c|c|}
\hline Stroke model/duration & Species/strain & Treatment/compound & Effect & References \\
\hline $\mathrm{MCAO} / 2 \mathrm{~h}$ & Rat/Wistar & Orally/statins & $\begin{array}{l}\text { Increased number of } \\
\mathrm{BrdU}^{+} \text {cells and } \\
\mathrm{BrdU}^{+} / \mathrm{Tuj}-1^{+} \\
\text {neuroblasts in SVZ }\end{array}$ & $\begin{array}{l}\text { Chen } \\
\text { et al. } 2003\end{array}$ \\
\hline $\mathrm{MCAO} / 90 \mathrm{~min}$ & Rat/SD & $\begin{array}{l}\text { Intraventricular } \\
\text { infusion/VEGF }\end{array}$ & $\begin{array}{l}\text { Increased survival of } \\
\text { progenitors }\left(\mathrm{BrdU}^{+}\right) \\
\text {in SVZ }\end{array}$ & $\begin{array}{c}\text { Sun et al. } \\
2003\end{array}$ \\
\hline $\mathrm{MCAO/permanent}$ & $\begin{array}{l}\text { Transgenic } \\
\text { mice/ } \\
\text { C57BL/6 }\end{array}$ & VEGF overexpression & $\begin{array}{l}\text { Increased number of } \\
\mathrm{BrdU}^{+} \text {cells and } \\
\mathrm{BrdU}^{+} / \mathrm{DCX}^{+} \\
\text {neuroblasts in SVZ; } \\
\text { increased number of } \\
\mathrm{BrdU}^{+} / \mathrm{NeuN}^{+} \text {new } \\
\text { neurons in cortex }\end{array}$ & $\begin{array}{l}\text { Wang et al. } \\
2007\end{array}$ \\
\hline $\mathrm{MCAO/permanent}$ & Rat/SD & $\begin{array}{l}\text { Subcutaneously/down- } \\
\text { regulator of T-cell } \\
\text { activity ( poly-YE) }\end{array}$ & $\begin{array}{l}\text { Increased number of new } \\
\left(\mathrm{BrdU}^{+} / \mathrm{MAP}^{+}\right) \\
\text {neurons in cortex }\end{array}$ & $\begin{array}{l}\text { Ziv et al. } \\
2007\end{array}$ \\
\hline $\begin{array}{l}\text { Distal MCAO/ } \\
\text { permanent }\end{array}$ & Mouse/SCID & $\begin{array}{l}\text { Intravenously/CD34 } \\
\text { cord blood cells }\end{array}$ & $\begin{array}{l}\text { Increased number of } \\
\text { PSA-NCAM }^{+} \\
\text {neuroblasts and } \\
\text { BrdU }^{+} / \mathrm{NeuN}^{+} \\
\text {neurons in cortex }\end{array}$ & $\begin{array}{l}\text { Taguchi } \\
\text { et al. } 2004\end{array}$ \\
\hline $\begin{array}{l}\text { Embolic MCAO/ } \\
\text { permanent }\end{array}$ & Rat/Wistar & $\begin{array}{l}\text { Intravenously/nitric } \\
\text { oxide donor }\end{array}$ & $\begin{array}{l}\text { Increased proliferation } \\
\quad\left(\mathrm{BrdU}^{+}\right) \text {in } \mathrm{SVZ}\end{array}$ & $\begin{array}{l}\text { Zhang et al. } \\
2001\end{array}$ \\
\hline $\begin{array}{l}\text { Distal MCAO/ } \\
\text { permanent }\end{array}$ & Mouse & $\begin{array}{l}\text { Subcutaneously/ } \\
\text { granulocyte colony- } \\
\text { stimulating factor (G- } \\
\text { CSF) and stem-cell } \\
\text { factor }\end{array}$ & $\begin{array}{c}\text { Increased number of SVZ } \\
\text { progenitors }\left(\mathrm{BrdU}^{+} /\right. \\
\left.\text {Musashi-1 }{ }^{+}\right)\end{array}$ & $\begin{array}{l}\text { Kawada } \\
\text { et al. } 2006\end{array}$ \\
\hline $\mathrm{MCAO} / 90 \mathrm{~min}$ & Rat/Wistar & Intravenously/G-CSF & $\begin{array}{l}\text { Increased number of } \\
\mathrm{DCX}^{+} \text {neuroblasts in } \\
\text { cortex }\end{array}$ & $\begin{array}{l}\text { Schneider } \\
\text { et al. } 2005\end{array}$ \\
\hline $\begin{array}{l}\text { Distal MCAO/ } \\
\text { permanent }\end{array}$ & $\begin{array}{l}\text { Rat/ } \\
\text { hypertensive }\end{array}$ & $\begin{array}{l}\text { Intracerebral injection/ } \\
\text { AAV-FGF-2 }\end{array}$ & $\begin{array}{l}\text { Increased number of } \\
\text { BrdU }^{+} \text {cells in SVZ; } \\
\text { increased number of } \\
\text { BrdU }^{+} \text {cells } \\
\text { coexpressing Sox } 2^{+}, \\
\text {Pax6 }^{+}, \mathrm{Hu} \text {, and NeuN } \\
\text { in peri-infarct cortex }\end{array}$ & $\begin{array}{l}\text { Leker et al. } \\
\quad 2007\end{array}$ \\
\hline $\mathrm{MCAO} / 30 \mathrm{~min}$ & Rat/SD & $\begin{array}{l}\text { Intraventricular } \\
\text { infusion } / \mathrm{Bcl}-2 \\
\text { plasmid }\end{array}$ & $\begin{array}{l}\text { Increased number of } \\
\text { BrdU }{ }^{+} \text {cells } \\
\text { coexpressing DCX and } \\
\text { ChAT in striatum, and } \\
\text { Tuj- } 1^{+}, \mathrm{MAP}^{+}, \\
\mathrm{GAD}^{+} 7^{+} \text {cells in } \\
\text { striatum and frontal } \\
\text { cortex }\end{array}$ & $\begin{array}{l}\text { Zhang et al. } \\
\text { 2006b }\end{array}$ \\
\hline $\mathrm{MCAO} / 90 \mathrm{~min}$ & Rat/SD & Exercise/running wheel & $\begin{array}{l}\text { Increased number of } \\
\text { Ki67 } 7^{+} \text {and IGF- } 1^{+} \text {cells }\end{array}$ & $\begin{array}{l}\text { Zhang et al. } \\
2013\end{array}$ \\
\hline
\end{tabular}


O. Lindvall and Z. Kokaia

Table 1. Continued

\begin{tabular}{|c|c|c|c|c|}
\hline Stroke model/duration & Species/strain & Treatment/compound & Effect & References \\
\hline $\mathrm{MCAO} /$ permanent & Rat/SD & $\begin{array}{l}\text { Subcutaneously/ } \\
\text { estradiol }\end{array}$ & $\begin{array}{l}\text { Increased number of } \\
\mathrm{BrdU}^{+}, \text {nestin }^{+}, \mathrm{DCX}^{+} \\
\text {and } \mathrm{BrdU}^{+} / \mathrm{DCX}^{+} \\
\text {cells in ipsilateral } \\
\text { SVZ }\end{array}$ & $\begin{array}{l}\text { Zheng et al. } \\
2013\end{array}$ \\
\hline $\mathrm{MCAO} /$ permanent & Rats/Wistar & $\begin{array}{l}\text { Intraperitoneally/ } \\
\text { cerebrolysin }\end{array}$ & $\begin{array}{l}\text { Increased number of } \\
\text { BrdU }^{+} \text {and } \mathrm{DCX}^{+} \text {cells } \\
\text { in ipsilateral SVZ and } \\
\text { striatal ischemic } \\
\text { boundary zone }\end{array}$ & $\begin{array}{l}\text { Zhang et al. } \\
2010\end{array}$ \\
\hline $\mathrm{MCAO} / 90 \mathrm{~min}$ & Rat/Wistar & $\begin{array}{l}\text { Application on cortical } \\
\text { surface/hepatocyte } \\
\text { growth factor }\end{array}$ & $\begin{array}{l}\text { Increased number of } \\
\mathrm{BrdU}^{+} \text {and } \mathrm{BrdU}^{+} / \\
\mathrm{DCX}^{+} \text {cells in } \\
\text { ipsilateral SVZ }\end{array}$ & $\begin{array}{l}\text { Shang et al. } \\
2011\end{array}$ \\
\hline $\begin{array}{l}\text { Photothrombotic } \\
\text { stroke }\end{array}$ & Rat/Wistar & $\begin{array}{l}\text { Intraperitoneally/ } \\
\text { citicoline }\end{array}$ & $\begin{array}{l}\text { Increased number of } \\
\mathrm{BrdU}^{+} \text {and BrdU } \\
\mathrm{NeuN}^{+} \text {cells in } \\
\text { ipsilateral SVZ, dentate } \\
\text { gyrus and peri-infarct } \\
\text { cortical area }\end{array}$ & $\begin{array}{l}\text { Diederich } \\
\text { et al. } 2012\end{array}$ \\
\hline $\begin{array}{l}\text { Photothrombotic } \\
\text { stroke }\end{array}$ & Rat/Wistar & $\begin{array}{l}\text { Osmotic minipump into } \\
\text { lesioned cortex/BDNF }\end{array}$ & $\begin{array}{l}\text { Increased number of } \\
\mathrm{BrdU}^{+} \text {and BrdU } \\
\mathrm{DCX}^{+} \text {cells in } \\
\text { perilesional cortical } \\
\text { area }\end{array}$ & $\begin{array}{l}\text { Keiner et al. } \\
2009\end{array}$ \\
\hline $\mathrm{MCAO} / 45 \mathrm{~min}$ & $\begin{array}{l}\text { Mouse/ } \\
\text { C57BL/6 }\end{array}$ & $\begin{array}{l}\text { Intraperitoneally/ } \\
\text { cilostazol }\end{array}$ & $\begin{array}{l}\text { Increased number of } \\
\mathrm{BrdU}^{+} \text {and } \mathrm{DCX}^{+} \text {cells } \\
\text { in } \mathrm{SVZ} \text { and peri-infarct } \\
\text { area }\end{array}$ & $\begin{array}{c}\text { Tanaka et al. } \\
2010\end{array}$ \\
\hline $\mathrm{MCAO} / 90 \mathrm{~min}$ & Rat/SD & $\begin{array}{l}\text { Enriched environment } \\
\text { and retinoic acid diet }\end{array}$ & $\begin{array}{l}\text { Increased number of } \\
\mathrm{DCX}^{+} \text {cells in SVZ and } \\
\mathrm{BrdU}^{+} / \mathrm{NeuN}^{+} \\
\text {neurons in striatum }\end{array}$ & $\begin{array}{l}\text { Plane et al. } \\
2008\end{array}$ \\
\hline $\mathrm{MCAO} /$ permanent & Rat/SD & $\begin{array}{l}\text { Functional electrical } \\
\text { stimulation }\end{array}$ & $\begin{array}{l}\text { Increased number of } \\
\mathrm{BrdU}^{+} / \mathrm{DCX}^{+} \text {cells in } \\
\mathrm{SVZ}\end{array}$ & $\begin{array}{c}\text { Liu et al. } \\
2013\end{array}$ \\
\hline
\end{tabular}

MCAO, Middle cerebral artery occlusion; GDNF, glial cell-derived neurotrophic factor; DCX, doublecortin; BDNF, brainderived neurotrophic factor; EPO, erythropoietin; EGF, epidermal growth factor; SVZ, subventricular zone; GFAP, glial fibrillary acidic protein; VEGF, vascular endothelial growth factor; HB-EGF, heparin-binding EGF; FGF, fibroblast growth factor; AAV, adeno-associated virus; rAAV, recombinant AAV.

parvalbumin after stroke in mice, which had been infused with EGF. Similarly, Liu et al. (2009) found no new striatal cells, labeled with BrdU or a retroviral GFP reporter, expressing markers of medium-sized spiny neurons (DARP-32 and calbindin). The SVZ-derived striatal cells differentiated exclusively into calretinin-expressing interneurons (Liu et al. 2009).
Regional heterogeneity of SVZ progenitors may be one reason for these discrepancies (Merkle et al. 2007). It is interesting to note, though, that under normal conditions in humans, calretinin-expressing interneurons but no DARPP$32^{+}$neurons were formed in the striatum (Ernst et al. 2014). Whether this finding indicates that there is a difference between humans and 
rodents in the subtype of neurons generated in SVZ following stroke remains to be elucidated.

\section{Morphological and Functional Integration}

When new striatal neurons are generated by adenoviral overexpression of BDNF and Noggin in the ventricular wall of intact animals, the new neurons establish efferent connections with neurons in the globus pallidus (Chmielnicki et al. 2004). Yamashita et al. (2006) have reported that the axons of the stroke-induced new striatal neurons contain abundant presynaptic vesicles and form synapses with neighboring cells, indicating some level of integration into existing neural circuitries. Recently, Sun et al. (2012) provided evidence that a population of the new striatal neurons reestablished the striatal projection to the substantia nigra in the stroke-injured brain of adult rats. BrdU and NeuN staining and intraventricular injection of a retroviral-GFP vector were used to label new neurons, which was combined with microinjection of the retrograde tracer Fluorogold (FG) into substantia nigra. Interestingly, $\mathrm{FG}^{+}$ new neurons (also $\mathrm{BrdU}^{+} / \mathrm{NeuN}^{+}$and $\mathrm{GFP}^{+} /$ $\mathrm{NeuN}^{+}$) were detected in the ipsilateral striatum at 12 wk but not $2 \mathrm{wk}$ after MCAO. This finding indicates that the new striatal neurons can form long axons targeting the substantia nigra. Sun et al. (2012) also obtained immunohistochemical evidence for the expression of dopamine and glutamate receptors on the stroke-induced striatal neurons, raising the possibility that they may respond to cortical glutamatergic and nigral dopaminergic inputs similar to striatal neurons in intact brain.

A crucial question is whether the new cells develop into neurons with the functional properties, including synaptic connectivity, characteristic of those neurons that they should replace. Hou et al. (2008) observed that the stroke-induced striatal neurons exhibited a time-dependent increase in dendrite length and branch formation. The new neurons expressed phosphorylated synapsin I and showed typical synaptic structures comprising dendrites and spines. Importantly, both the presumed GABAergic and cholinergic new striatal neu- rons, labeled with DiI, injected in the ventricle, and BrdU, fired action potentials and received excitatory and inhibitory synaptic inputs. This study provides the first experimental evidence that the ischemia-induced new striatal neurons can become functionally integrated into neural networks in the adult brain after stroke.

Another important issue is how the characteristics of the pathological environment influence the development of the functional synaptic connectivity of the new neurons. For the neurons generated after stroke, this is virtually unknown. When new hippocampal neurons are produced in an environment characterized by status epilepticus (Jakubs et al. 2006) or LPSinduced microglial activation (Jakubs et al. 2008), they develop increased inhibitory drive at their afferent synapses. Conversely, in a less severe seizure environment, without prominent microglial activation, this increase in inhibitory input is not observed (Wood et al. 2011). Thus, it seems that following insults to the adult brain, the pattern of synaptic alterations at afferent inputs to newly generated neurons, which could determine whether neurogenesis counteracts or exacerbates pathological effects, is dependent on the characteristics of the environment, including the cross talk with immune cells (Kokaia et al. 2012).

\section{STRATEGIES TO STIMULATE ISCHEMIA- INDUCED NEUROGENESIS}

It is important to emphasize that neurogenesis after stroke is not just one process but comprises several steps: (1) proliferation of NSPCs, (2) survival of immature or mature neurons, (3) migration of new neuroblasts to appropriate location, (4) differentiation of new neuroblasts to phenotype of neurons that need to be replaced, and (5) development of functional synaptic connectivity counteracting disease symptoms. Considering our own findings of long-term neurogenesis after stroke, one could argue that the main problem for effectiveness is not insufficient production of new neuroblasts. Therefore, the proliferation step may not be the most suitable target but the major emphasis should probably be put on approaches improv- 
ing the survival of newly formed neuroblasts and their differentiation to mature neurons.

Many approaches have been reported to promote neurogenesis after stroke (Table 1) and some of them have been associated with improved functional recovery. Of particular interest in a therapeutic perspective are those strategies that could be applicable also in a clinical setting. For example, intrastriatal infusion of glial cell-derived neurotrophic factor (GDNF) increased cell proliferation in ipsilateral SVZ and recruitment of new neuroblasts into the striatum after MCAO, and improved survival of new mature neurons (Kobayashi et al. 2006). Similar intrastriatal infusion of GDNF protein has been shown to induce sprouting of dopaminergic neurons in a Parkinson's patient (Love et al. 2005). Thus, administration of this factor may become of therapeutic value to promote neuroregenerative responses in stroke patients.

Recently, it was reported that transplantation of human embryonic stem-cell-derived NSPCs into the cortical infarct caused by distal MCAO in rats increased the number of $\mathrm{DCX}^{+}$cells in SVZ (Jin et al. 2011), and that human fetal NSPCs implanted into the cortical peri-infarct area in rats with permanent MCAO promoted cell proliferation in SVZ (Zhang et al. 2011). Mine et al. (2013) showed that human fetal NSPCs implanted into the striatum after stroke increased the numbers of proliferating cells in SVZ and new SVZ-derived migrating neuroblasts and mature neurons in the striatum. This enhancement of endogenous neurogenesis was associated with improved behavioral recovery. These findings support the idea that in a future clinical setting, the most effective NSPC-based approach for cell therapy after stroke probably combines transplantation of NSPCs with stimulation of endogenous neurogenesis.

\section{FUNCTIONAL CONSEQUENCES OF ISCHEMIA-INDUCED NEUROGENESIS}

Although there is a bulk of indirect evidence suggesting an association between endogenous neurogenesis and stroke recovery, a direct causal link needs to be established (Lagace 2012). Spontaneous motor recovery after stroke in rats affecting only the striatum occurred over several months concomitantly with striatal neurogenesis (Thored et al. 2006). Administration of molecules that promote neural proliferation in the SVZ and striatal neurogenesis after stroke (see Table 1) has been reported to be associated with improved functional outcome. Recent attempts to ablate $\mathrm{DCX}^{+} \mathrm{SVZ}$ neuroblasts to determine the contribution of these cells to poststroke behavioral recovery did not give clear results. Genetic ablation of newly formed neuroblasts in transgenic mice caused worsening of postischemic behavioral deficits and more extensive ischemic lesion as early as $24 \mathrm{~h}$ after $\mathrm{MCAO}$, which makes it inconceivable that a lack of new mature neurons replacing the dead ones had contributed to the observed effect. It seems more likely that the newly generated neuroblast exerted a trophic action at this early time point, but the findings do not exclude the possibility that functional improvement may occur through neuronal replacement later after stroke (Jin et al. 2010). In a follow-up study, the effect on infarct volume was shown to be maintained at $12 \mathrm{wk}$ after distal MCAO, whereas the behavioral deficits, which were greater in the mice subjected to neuroblast ablation during the first $8 \mathrm{wk}$, were completely reversed at $12 \mathrm{wk}$ in parallel to restoration of neurogenesis (Wang et al. 2012). Taken together, these data support the idea that endogenous neurogenesis can induce improved outcome after stroke, although the mechanisms of action of the new neurons still are unclear.

Recent experimental evidence suggests that NSPCs in SVZ may also have a homeostatic regulatory role and protect striatal neurons from glutamate-induced excitotoxicity after stroke (Butti et al. 2012). Selective ablation of SVZ NSPCs in transgenic mice using ganciclovir increased the frequency and duration of glutamate-evoked spontaneous excitatory postsynaptic currents in striatal medium-sized spiny neurons in acute brain slices. Stroke in these animals caused increased mortality and larger lesion volume. The protective effect of SVZ NSPCs was probably a result of secretion of endocannabinoids, which were shown to reverse both the electrophysiological alterations and 
mitigate the ischemic injury caused by NSPC ablation (Butti et al. 2012).

\section{CONCLUDING REMARKS}

The demonstration of a mechanism by which endogenous NSCPs generate new neurons migrating toward the ischemically damaged area after a stroke affecting the adult brain has raised a lot of interest in both the scientific and clinical community. It is now a major challenge to determine how the reservoirs of NSPCs located in the SVZ and SGZ could be efficiently recruited for repair of the stroke-damaged brain. However, many fundamental issues remain to be addressed regarding this potential self-repair mechanism. Most important, we need more solid data demonstrating the role of endogenous neurogenesis for functional restoration after stroke. Also, we need to develop strategies to optimize neurogenesis by generating sufficient numbers of new, functionally integrated neurons with the correct phenotype, which survive in the pathological environment.

Obviously, more knowledge about mechanisms of cell proliferation, differentiation, migration, survival, and functional integration in stroke-induced neurogenesis, as well as about the occurrence of this mechanism in patients, is needed. Also, what is the maximum level of improvement after stroke that may be achieved by neurogenesis? Because stroke-induced neurogenesis can continue for many months (Thored et al. 2006), various interventions to promote neurogenesis are not restricted to the acute postischemic period but can be applied over an extended time period. It seems unlikely that stimulation of neurogenesis from endogenous stem cells per se could be developed into a novel therapeutic approach and provide optimum repair of the stroke-damaged brain. Such a strategy probably needs to be combined with transplantation of NSPCs or their progeny in the vicinity to the damaged area. For efficient repair, it may also be necessary to provide the new cells, generated from endogenous and grafted stem cells, with a platform in the form of synthetic extracellular matrix so that they can reform appropriate brain structure.

\section{ACKNOWLEDGMENTS}

Our research is supported by the Swedish Research Council, European Union 7th Framework Program through the consortium TargetBrain (Grant No. 279017), AFA Foundation, and the Swedish Government Initiative for Strategic Research Areas (StemTherapy).

\section{REFERENCES}

Ahlenius H, Devaraju K, Monni E, Oki K, Wattananit S, Darsalia V, Iosif RE, Torper O, Wood JC, Braun S, et al. 2012. Adaptor protein LNK is a negative regulator of brain neural stem cell proliferation after stroke. J Neurosci 32: $5151-5164$.

Androutsellis-Theotokis A, Leker RR, Soldner F, Hoeppner DJ, Ravin R, Poser SW, Rueger MA, Bae SK, Kittappa R, McKay RD. 2006. Notch signalling regulates stem cell numbers in vitro and in vivo. Nature 442: 823-826.

Arvidsson A, Collin T, Kirik D, Kokaia Z, Lindvall O. 2002. Neuronal replacement from endogenous precursors in the adult brain after stroke. Nat Med 8: 963-970.

Barkho BZ, Munoz AE, Li X, Li L, Cunningham LA, Zhao X. 2008. Endogenous matrix metalloproteinase (MMP)-3 and MMP-9 promote the differentiation and migration of adult neural progenitor cells in response to chemokines. Stem Cells 26: 3139-3149.

Bernier PJ, Vinet J, Cossette M, Parent A. 2000. Characterization of the subventricular zone of the adult human brain: Evidence for the involvement of Bcl-2. Neurosci Res 37: 67-78

Bhardwaj RD, Curtis MA, Spalding KL, Buchholz BA, Fink D, Björk-Eriksson T, Nordborg C, Gage FH, Druid H Eriksson PS, Frisén J. 2006. Neocortical neurogenesis in humans is restricted to development. Proc Natl Acad Sci 103: $12564-12568$.

Breunig JJ, Arellano JI, Macklis JD, Rakic P. 2007. Everything that glitters isn't gold: A critical review of postnatal neural precursor analyses. Cell Stem Cell 1: 612-627.

Butovsky O, Ziv Y, Schwartz A, Landa G, Talpalar AE, Pluchino S, Martino G, Schwartz M. 2006. Microglia activated by IL- 4 or IFN- $\gamma$ differentially induce neurogenesis and oligodendrogenesis from adult stem/progenitor cells. Mol Cell Neurosci 31: 149-160.

Butti E, Bacigaluppi M, Rossi S, Cambiaghi M, Bari M, Cebrian Silla A, Brambilla E, Musella A, De Ceglia R Teneud L, et al. 2012. Subventricular zone neural progenitors protect striatal neurons from glutamatergic excitotoxicity. Brain 135: 3320-3335.

Buza-Vidas N, Antonchuk J, Qian H, Mansson R, Luc S, Zandi S, Anderson K, Takaki S, Nygren JM, Jensen CT, Jacobsen SE. 2006. Cytokines regulate postnatal hematopoietic stem cell expansion: Opposing roles of thrombopoietin and LNK. Genes Dev 20: 2018-2023.

Cacci E, Ajmone-Cat MA, Anelli T, Biagioni S, Minghetti L. 2008. In vitro neuronal and glial differentiation from embryonic or adult neural precursor cells are differently affected by chronic or acute activation of microglia. Glia 56: $412-425$. 
Carlen M, Meletis K, Goritz C, Darsalia V, Evergren E, Tanigaki $\mathrm{K}$, Amendola $\mathrm{M}$, Barnabe-Heider F, Yeung MS, Naldini L, et al. 2009. Forebrain ependymal cells are Notch-dependent and generate neuroblasts and astrocytes after stroke. Nat Neurosci 12: 259-267.

Chen J, Zhang ZG, Li Y, Wang Y, Wang L, Jiang H, Zhang C, Lu M, Katakowski M, Feldkamp CS, Chopp M. 2003. Statins induce angiogenesis, neurogenesis, and synaptogenesis after stroke. Ann Neurol 53: 743-751.

Chmielnicki E, Benraiss A, Economides AN, Goldman SA. 2004. Adenovirally expressed noggin and brain-derived neurotrophic factor cooperate to induce new medium spiny neurons from resident progenitor cells in the adult striatal ventricular zone. J Neurosci 24: 2133-2142.

Collin T, Arvidsson A, Kokaia Z, Lindvall O. 2005. Quantitative analysis of the generation of different striatal neuronal subtypes in the adult brain following excitotoxic injury. Exp Neurol 195: 71-80.

Curtis MA, Kam M, Nannmark U, Anderson MF, Axell MZ Wikkelso C, Holtas S, van Roon-Mom WM, Bjork-Eriksson T, Nordborg C, et al. 2007. Human neuroblasts migrate to the olfactory bulb via a lateral ventricular extension. Science 315: 1243-1249.

Darsalia V, Heldmann U, Lindvall O, Kokaia Z. 2005. Strokeinduced neurogenesis in aged brain. Stroke 36: 17901795.

Delavaran H, Sjunnesson H, Arvidsson A, Lindvall O, Norrving B, van Westen D, Kokaia Z, Lindgren A. 2013. Proximity of brain infarcts to regions of endogenous neurogenesis and involvement of striatum in ischaemic stroke. Eur J Neurol 20: 473-479.

Devaraju K, Barnabe-Heiderb F, Kokaia Z, Lindvall O. 2013. FoxJ1-expressing cells contribute to neurogenesis in forebrain of adult rats: Evidence from in vivo electroporation combined with piggyBac transposon. Exp Cell Res 319: 2790-2800.

Diederich K, Frauenknecht K, Minnerup J, Schneider BK, Schmidt A, Altach E, Eggert V, Sommer CJ, Schabitz WR 2012. Citicoline enhances neuroregenerative processes after experimental stroke in rats. Stroke 43: 1931-1940.

Ekdahl CT, Claasen JH, Bonde S, Kokaia Z, Lindvall O. 2003. Inflammation is detrimental for neurogenesis in adult brain. Proc Natl Acad Sci 100: 13632-13637.

Eriksson PS, Perfilieva E, Björk-Eriksson T, Alborn AM, Nordborg C, Peterson DA, Gage FH. 1998. Neurogenesis in the adult human hippocampus. Nat Med 4: 13131317.

Ernst A, Alkass K, Bernard S, Salehpour M, Perl S, Tisdale J, Possnert G, Druid H, Frisén J. 2014. Neurogenesis in the striatum of the adult human brain. Cell 156: 1072-1083.

Gomez-Nicola D, Valle-Argos B, Pallas-Bazarra N, NietoSampedro M. 2011. Interleukin-15 regulates proliferation and self-renewal of adult neural stem cells. Mol Biol Cell 22: 1960-1970.

Gonzalez CL, Kolb B. 2003. A comparison of different models of stroke on behaviour and brain morphology. Eur J Neurosci 18: 1950-1962.

Grade S, Weng YC, Snapyan M, Kriz J, Malva JO, Saghatelyan A. 2013. Brain-derived neurotrophic factor promotes vasculature-associated migration of neuronal precursors toward the ischemic striatum. PloS ONE 8: e55039.
Gu W, Jiang W, Wester P. 1999. A photothrombotic ring stroke model in rats with sustained hypoperfusion followed by late spontaneous reperfusion in the region at risk. Exp Brain Res 125: 163-170.

Gustafsson E, Andsberg G, Darsalia V, Mohapel P, Mandel RJ, Kirik D, Lindvall O, Kokaia Z. 2003. Anterograde delivery of brain-derived neurotrophic factor to striatum via nigral transduction of recombinant adeno-associated virus increases neuronal death but promotes neurogenic response following stroke. Eur J Neurosci 17: 2667-2678.

Hoehn BD, Palmer TD, Steinberg GK. 2005. Neurogenesis in rats after focal cerebral ischemia is enhanced by indomethacin. Stroke 36: 2718-2724.

Hou SW, Wang YQ, Xu M, Shen DH, Wang JJ, Huang F, Yu Z, Sun FY. 2008. Functional integration of newly generated neurons into striatum after cerebral ischemia in the adult rat brain. Stroke 39: 2837-2844.

Huttner HB, et al. 2014. The age and genomic integrity of neurons after cortical stroke in humans. Nat Neurosci 17: 801-803.

Iosif RE, Ahlenius H, Ekdahl CT, Darsalia V, Thored P, Jovinge S, Kokaia Z, Lindvall O. 2008. Suppression of stroke-induced progenitor proliferation in adult subventricular zone by tumor necrosis factor receptor 1. J Cereb Blood Flow Metab 28: 1574-1587.

Jakubs K, Nanobashvili A, Bonde S, Ekdahl CT, Kokaia Z, Kokaia M, Lindvall O. 2006. Environment matters: Synaptic properties of neurons born in the epileptic adult brain develop to reduce excitability. Neuron 52: 10471059.

Jakubs K, Bonde S, Iosif RE, Ekdahl CT, Kokaia Z, Kokaia M, Lindvall O. 2008. Inflammation regulates functional integration of neurons born in adult brain. J Neurosci $\mathbf{2 8}$ $12477-12488$.

Jiang W, Gu W, Brannstrom T, Rosqvist R, Wester P. 2001. Cortical neurogenesis in adult rats after transient middle cerebral artery occlusion. Stroke 32: 1201-1207.

Jin K, Minami M, Lan JQ, Mao XO, Batteur S, Simon RP, Greenberg DA. 2001. Neurogenesis in dentate subgranular zone and rostral subventricular zone after focal cerebral ischemia in the rat. Proc Natl Acad Sci 98: 4710-4715.

Jin K, Sun Y, Xie L, Peel A, Mao XO, Batteur S, Greenberg DA. 2003. Directed migration of neuronal precursors into the ischemic cerebral cortex and striatum. Mol Cell Neurosci 24: 171-189.

Jin K, Sun Y, Xie L, Childs J, Mao XO, Greenberg DA. 2004. Post-ischemic administration of heparin-binding epidermal growth factor-like growth factor (HB-EGF) reduces infarct size and modifies neurogenesis after focal cerebral ischemia in the rat. J Cereb Blood Flow Metab 24: 399408.

Jin K, Wang X, Xie L, Mao XO, Zhu W, Wang Y, Shen J, Mao Y, Banwait S, Greenberg DA. 2006. Evidence for strokeinduced neurogenesis in the human brain. Proc Natl Acad Sci 103: $13198-13202$.

Jin K, Wang X, Xie L, Mao XO, Greenberg DA. 2010. Transgenic ablation of doublecortin-expressing cells suppresses adult neurogenesis and worsens stroke outcome in mice. Proc Natl Acad Sci 107: 7993-7998.

Jin K, Xie L, Mao X, Greenberg MB, Moore A, Peng B, Greenberg RB, Greenberg DA. 2011. Effect of human neural precursor cell transplantation on endogenous 
neurogenesis after focal cerebral ischemia in the rat Brain Res 1374: 56-62.

Kawada H, Takizawa S, Takanashi T, Morita Y, Fujita J, Fukuda K, Takagi S, Okano H, Ando K, Hotta T. 2006. Administration of hematopoietic cytokines in the subacute phase after cerebral infarction is effective for functional recovery facilitating proliferation of intrinsic neu$\mathrm{ral} \mathrm{stem/progenitor} \mathrm{cells} \mathrm{and} \mathrm{transition} \mathrm{of} \mathrm{bone} \mathrm{marrow-}$ derived neuronal cells. Circulation 113: 701-710.

Keiner S, Witte OW, Redecker C. 2009. Immunocytochemical detection of newly generated neurons in the perilesional area of cortical infarcts after intraventricular application of brain-derived neurotrophic factor. J Neuropathol Exp Neurol 68: 83-93.

Kobayashi T, Ahlenius H, Thored P, Kobayashi R, Kokaia Z, Lindvall O. 2006. Intracerebral infusion of glial cell linederived neurotrophic factor promotes striatal neurogenesis after stroke in adult rats. Stroke 37: 2361-2367.

Kojima T, Hirota Y, Ema M, Takahashi S, Miyoshi I, Okano H, Sawamoto K. 2010. Subventricular zone-derived neural progenitor cells migrate along a blood vessel scaffold toward the post-stroke striatum. Stem Cells 28: 545-554.

Kokaia Z, Martino G, Schwartz M, Lindvall O. 2012. Crosstalk between neural stem cells and immune cells: The key to better brain repair? Nat Neurosci 15: 1078-1087.

Kolb B, Morshead C, Gonzalez C, Kim M, Gregg C, Shingo T, Weiss S. 2006. Growth factor-stimulated generation of new cortical tissue and functional recovery after stroke damage to the motor cortex of rats. J Cereb Blood Flow Metab 27: 983-997.

Kolb B, Morshead C, Gonzalez C, Kim M, Gregg C, Shingo T, Weiss S. 2007. Growth factor-stimulated generation of new cortical tissue and functional recovery after stroke damage to the motor cortex of rats. J Cereb Blood Flow Metab 27: 983-997.

Kreuzberg M, Kanov E, Timofeev O, Schwaninger M, Monyer H, Khodosevich K. 2010. Increased subventricular zone-derived cortical neurogenesis after ischemic lesion. Exp Neurol 226: 90-99.

Lagace DC. 2012. Does the endogenous neurogenic response alter behavioral recovery following stroke? Behav Brain Res 227: 426-432.

Lee SR, Kim HY, Rogowska J, Zhao BQ, Bhide P, Parent JM, Lo EH. 2006. Involvement of matrix metalloproteinase in neuroblast cell migration from the subventricular zone after stroke. J Neurosci 26: 3491-3495.

Leifer D, Kowall NW. 1993. Immunohistochemical patterns of selective cellular vulnerability in human cerebral ischemia. J Neurol Sci 119: 217-228.

Leker RR, Soldner F, Velasco I, Gavin DK, AndroutsellisTheotokis A, McKay RD. 2007. Long-lasting regeneration after ischemia in the cerebral cortex. Stroke 38: 153-161.

Liu Z, Fan Y, Won SJ, Neumann M, Hu D, Zhou L, Weinstein PR, Liu J. 2007. Chronic treatment with minocycline preserves adult new neurons and reduces functional impairment after focal cerebral ischemia. Stroke 38: 146-152.

Liu F, You Y, Li X, Ma T, Nie Y, Wei B, Li T, Lin H, Yang Z. 2009. Brain injury does not alter the intrinsic differentiation potential of adult neuroblasts. J Neurosci 29: 50755087.
Neurogenesis following Stroke in the Adult Brain

Liu K, Liu Y, Mo W, Qiu R, Wang X, Wu JY, He R. 2011. MiR124 regulates early neurogenesis in the optic vesicle and forebrain, targeting NeuroD1. Nucleic Acids Res 39: 2869-2879.

Liu XS, Chopp M, Wang XL, Zhang L, Hozeska-Solgot A, Tang T, Kassis H, Zhang RL, Chen C, Xu J, Zhang ZG. 2013. MicroRNA-17-92 cluster mediates the proliferation and survival of neural progenitor cells after stroke. J Biol Chem 288: 12478-12488.

Louissaint A Jr, Rao S, Leventhal C, Goldman SA. 2002. Coordinated interaction of neurogenesis and angiogenesis in the adult songbird brain. Neuron 34: 945-960.

Love S, Plaha P, Patel NK, Hotton GR, Brooks DJ, Gill SS. 2005. Glial cell line-derived neurotrophic factor induces neuronal sprouting in human brain. Nat Med 11: $703-$ 704.

Macas J, Nern C, Plate KH, Momma S. 2006. Increased generation of neuronal progenitors after ischemic injury in the aged adult human forebrain. J Neurosci 26: 1311413119 .

Magnusson JP, Göritz C, Tatarishvili J, Dias DO, Smith EMK, Lindvall O, Kokaia Z, Frisén J. 2014. A latent neurogenic program in astrocytes regulated by Notch signaling in the mouse. Science 346: 237-241.

Marti-Fabregas J, Romaguera-Ros M, Gomez-Pinedo U, Martinez-Ramirez S, Jimenez-Xarrie E, Marin R, Marti-Vilalta JL, Garcia-Verdugo JM. 2010. Proliferation in the human ipsilateral subventricular zone after ischemic stroke. Neurology 74: 357-365.

Merkle FT, Mirzadeh Z, Alvarez-Buylla A. 2007. Mosaic organization of neural stem cells in the adult brain. Science 317: 381-384.

Mine Y, Tatarishvili J, Oki K, Monni E, Kokaia Z, Lindvall O. 2013. Grafted human neural stem cells enhance several steps of endogenous neurogenesis and improve behavioral recovery after middle cerebral artery occlusion in rats. Neurobiol Dis 52: 191-203.

Minger SL, Ekonomou A, Carta EM, Chinoy A, Perry RH, Ballard CG. 2007. Endogenous neurogenesis in the human brain following cerebral infarction. Regenerative Med 2: 69-74.

Monje ML, Toda H, Palmer TD. 2003. Inflammatory blockade restores adult hippocampal neurogenesis. Science 302: $1760-1765$

Nakayama D, Matsuyama T, Ishibashi-Ueda H, Nakagomi T, Kasahara Y, Hirose H, Kikuchi-Taura A, Stern DM, Mori H, Taguchi A. 2010. Injury-induced neural stem/ progenitor cells in post-stroke human cerebral cortex. Eur J Neurosci 31: 90-98.

Nyfeler Y, Kirch RD, Mantei N, Leone DP, Radtke F, Suter U, Taylor V. 2005. Jagged1 signals in the postnatal subventricular zone are required for neural stem cell self-renewal. EMBO J 24: 3504-3515.

Ohab JJ, Fleming S, Blesch A, Carmichael ST. 2006. A neurovascular niche for neurogenesis after stroke. J Neurosci 26: $13007-13016$.

Ohira K, Furuta T, Hioki H, Nakamura KC, Kuramoto E, Tanaka Y, Funatsu N, Shimizu K, Oishi T, Hayashi M, et al. 2010. Ischemia-induced neurogenesis of neocortical layer 1 progenitor cells. Nat Neurosci 13: 173-179. 
Osman AM, Porritt MJ, Nilsson M, Kuhn HG. 2011. Longterm stimulation of neural progenitor cell migration after cortical ischemia in mice. Stroke 42: 3559-3565.

Parent JM, Vexler ZS, Gong C, Derugin N, Ferriero DM. 2002. Rat forebrain neurogenesis and striatal neuron replacement after focal stroke. Ann Neurol 52: 802-813.

Plane JM, Whitney JT, Schallert T, Parent JM. 2008. Retinoic acid and environmental enrichment alter subventricular zone and striatal neurogenesis after stroke. Exp Neurol 214: $125-134$.

Robin AM, Zhang ZG, Wang L, Zhang RL, Katakowski M, Zhang L, Wang Y, Zhang C, Chopp M. 2005. Stromal cellderived factor $1 \alpha$ mediates neural progenitor cell motility after focal cerebral ischemia. J Cereb Blood Flow Metab 26: $125-134$.

Robin AM, Zhang ZG, Wang L, Zhang RL, Katakowski M, Zhang L, Wang Y, Zhang C, Chopp M. 2006. Stromal cellderived factor $1 \alpha$ mediates neural progenitor cell motility after focal cerebral ischemia. J Cereb Blood Flow Metab 26: $125-134$.

Saha B, Peron S, Murray K, Jaber M, Gaillard A. 2013. Cortical lesion stimulates adult subventricular zone neural progenitor cell proliferation and migration to the site of injury. Stem Cell Res 11: 965-977.

Saino O, Taguchi A, Nakagomi T, Nakano-Doi A, Kashiwamura S, Doe N, Nakagomi N, Soma T, Yoshikawa H, Stern DM, et al. 2010. Immunodeficiency reduces neural stem/progenitor cell apoptosis and enhances neurogenesis in the cerebral cortex after stroke. J Neurosci Res 88: 2385-2397.

Sanai N, Tramontin AD, Quinones-Hinojosa A, Barbaro NM, Gupta N, Kunwar S, Lawton MT, McDermott MW, Parsa AT, Manuel-Garcia Verdugo J, Berger MS, Alvarez-Buylla A. 2004. Unique astrocyte ribbon in adult human brain contains neural stem cells but lacks chain migration. Nature 427: 740-744.

Sanai N, Nguyen T, Ihrie RA, Mirzadeh Z, Tsai HH, Wong M, Gupta N, Berger MS, Huang E, Garcia-Verdugo JM, Rowitch DH, Alvarez-Buylla A. 2011. Corridors of migrating neurons in the human brain and their decline during infancy. Nature 478: 382-386.

Schneider A, Kruger C, Steigleder T, Weber D, Pitzer C, Laage R, Aronowski J, Maurer MH, Gassler N, Mier W, Hasselblatt M, Kollmar R, Schwab S, Sommer C, Bach A, Kuhn HG, Schabitz WR. 2005. The hematopoietic factor G-CSF is a neuronal ligand that counteracts programmed cell death and drives neurogenesis. J Clin Invest 115: 2083-2098.

Shang J, Deguchi K, Ohta Y, Liu N, Zhang X, Tian F, Yamashita T, Ikeda Y, Matsuura T, Funakoshi H, et al. 2011. Strong neurogenesis, angiogenesis, synaptogenesis, and antifibrosis of hepatocyte growth factor in rats brain after transient middle cerebral artery occlusion. J Neurosci Res 89: 86-95.

Spalding KL, Bergmann O, Alkass K, Bernard S, Salehpour M, Huttner HB, Bostrom E, Westerlund I, Vial C, Buchholz BA, et al. 2013. Dynamics of hippocampal neurogenesis in adult humans. Cell 153: 1219-1227.

Stump G, Durrer A, Klein AL, Lutolf S, Suter U, Taylor V. 2002. Notch1 and its ligands Delta-like and Jagged are expressed and active in distinct cell populations in the postnatal mouse brain. Mech Dev 114: 153-159.
Sun Y, Jin K, Xie L, Childs J, Mao XO, Logvinova A, Greenberg DA. 2003. VEGF-induced neuroprotection, neurogenesis, and angiogenesis after focal cerebral ischemia. J Clin Invest 111: 1843-1851.

Sun X, Zhang QW, Xu M, Guo JJ, Shen SW, Wang YQ, Sun FY. 2012. New striatal neurons form projections to substantia nigra in adult rat brain after stroke. Neurobiol Dis 45: 601-609.

Taguchi A, Soma T, Tanaka H, Kanda T, Nishimura H, Yoshikawa H, Tsukamoto Y, Iso H, Fujimori Y, Stern DM, Naritomi H, Matsuyama T. 2004. Administration of $\mathrm{CD} 34^{+}$cells after stroke enhances neurogenesis via angiogenesis in a mouse model. J Clin Invest 114: 330-338.

Takaki S, Sauer K, Iritani BM, Chien S, Ebihara Y, Tsuji K, Takatsu K, Perlmutter RM. 2000. Control of B cell production by the adaptor protein lnk. Definition of a conserved family of signal-modulating proteins. Immunity 13: 599-609.

Takata M, Nakagomi T, Kashiwamura S, Nakano-Doi A, Saino O, Nakagomi N, Okamura H, Mimura O, Taguchi A, Matsuyama T. 2012. Glucocorticoid-induced TNF receptor-triggered T cells are key modulators for survival/ death of neural stem/progenitor cells induced by ischemic stroke. Cell Death Differ 19: 756-767.

Tanaka Y, Tanaka R, Liu M, Hattori N, Urabe T. 2010. Cilostazol attenuates ischemic brain injury and enhances neurogenesis in the subventricular zone of adult mice after transient focal cerebral ischemia. Neuroscience 171 1367-1376.

Teramoto T, Qiu J, Plumier JC, Moskowitz MA. 2003. EGF amplifies the replacement of parvalbumin-expressing striatal interneurons after ischemia. J Clin Invest 111: $1125-1132$.

Thored P, Arvidsson A, Cacci E, Ahlenius H, Kallur T, Darsalia V, Ekdahl CT, Kokaia Z, Lindvall O. 2006. Persistent production of neurons from adult brain stem cells during recovery after stroke. Stem Cells 24: 739-747.

Thored P, Wood J, Arvidsson A, Cammenga J, Kokaia Z, Lindvall O. 2007. Long-term neuroblast migration along blood vessels in an area with transient angiogenesis and increased vascularization after stroke. Stroke 38: 3032 3039.

Thored P, Heldmann U, Gomes-Leal W, Gisler R, Darsalia V, Taneera J, Nygren JM, Jacobsen SE, Ekdahl CT, Kokaia Z, Lindvall O. 2009. Long-term accumulation of microglia with proneurogenic phenotype concomitant with persistent neurogenesis in adult subventricular zone after stroke. Glia 57: 835-849.

Tsai PT, Ohab JJ, Kertesz N, Groszer M, Matter C, Gao J, Liu X, Wu H, Carmichael ST. 2006. A critical role of erythropoietin receptor in neurogenesis and post-stroke recovery. J Neurosci 26: 1269-1274.

Walton NM, Sutter BM, Laywell ED, Levkoff LH, Kearns SM, Marshall GP 2nd, Scheffler B, Steindler DA. 2006. Microglia instruct subventricular zone neurogenesis. Glia 54: 815-825.

Wang L, Zhang Z, Zhang R, Hafner MS, Wong HK, Jiao Z, Chopp M. 2004. Erythropoietin up-regulates SOCS2 in neuronal progenitor cells derived from SVZ of adult rat. Neuroreport 15: 1225-1229. 
Wang H, Ward N, Boswell M, Katz DM. 2006. Secretion of brain-derived neurotrophic factor from brain microvascular endothelial cells. Eur J Neurosci 23: 1665-1670.

Wang Y, Jin K, Mao XO, Xie L, Banwait S, Marti HH, Greenberg DA. 2007. VEGF-overexpressing transgenic mice show enhanced post-ischemic neurogenesis and neuromigration. J Neurosci Res 85: 740-747.

Wang L, Chopp M, Zhang RL, Zhang L, Letourneau Y, Feng YF, Jiang A, Morris DC, Zhang ZG. 2009a. The Notch pathway mediates expansion of a progenitor pool and neuronal differentiation in adult neural progenitor cells after stroke. Neuroscience 158: 1356-1363.

Wang X, Mao X, Xie L, Greenberg DA, Jin K. 2009b. Involvement of Notchl signaling in neurogenesis in the subventricular zone of normal and ischemic rat brain in vivo. J Cereb Blood Flow Metab 29: 1644-1654.

Wang X, Mao X, Xie L, Sun F, Greenberg DA, Jin K. 2012. Conditional depletion of neurogenesis inhibits long-term recovery after experimental stroke in mice. PloS ONE 7: e38932.

Wolf SA, Steiner B, Wengner A, Lipp M, Kammertoens T, Kempermann G. 2009. Adaptive peripheral immune response increases proliferation of neural precursor cells in the adult hippocampus. FASEB J 23: 3121-3128.

Wood JC, Jackson JS, Jakubs K, Chapman KZ, Ekdahl CT, Kokaia Z, Kokaia M, Lindvall O. 2011. Functional integration of new hippocampal neurons following insults to the adult brain is determined by characteristics of pathological environment. Exp Neurol 229: 484-493.

Yamashita T, Ninomiya M, Hernandez Acosta P, Garcia-Verdugo JM, Sunabori T, Sakaguchi M, Adachi K, Kojima T, Hirota Y, Kawase T, et al. 2006. Subventricular zone-derived neuroblasts migrate and differentiate into mature neurons in the post-stroke adult striatum. J Neurosci 26: 6627-6636.

Yan YP, Sailor KA, Lang BT, Park SW, Vemuganti R, Dempsey RJ. 2007. Monocyte chemoattractant protein-1 plays a critical role in neuroblast migration after focal cerebral ischemia. J Cereb Blood Flow Metab 27: 1213-1224.

Yan YP, Lang BT, Vemuganti R, Dempsey RJ. 2009. Osteopontin is a mediator of the lateral migration of neuroblasts from the subventricular zone after focal cerebral ischemia. Neurochem Int 55: 826-832.

Young CC, van der Harg JM, Lewis NJ, Brooks KJ, Buchan AM, Szele FG. 2013. Ependymal ciliary dysfunction and reactive astrocytosis in a reorganized subventricular zone after stroke. Cereb Cortex 23: 647-659.

Zhang RL, Chopp M, Zhang ZG, Jiang Q, Ewing JR. 1997. A rat model of focal embolic cerebral ischemia. Brain Res 766: 83-92.

Zhang R, Zhang L, Zhang Z, Wang Y, Lu M, Lapointe M, Chopp M. 2001. A nitric oxide donor induces neurogenesis and reduces functional deficits after stroke in rats. Ann Neurol 50: 602-611.

Zhang R, Wang Y, Zhang L, Zhang Z, Tsang W, Lu M, Zhang L, Chopp M. 2002. Sildenafil (Viagra) induces neurogenesis and promotes functional recovery after stroke in rats. Stroke 33: 2675-2680.

Zhang R, Zhang Z, Zhang C, Zhang L, Robin A, Wang Y, Lu M, Chopp M. 2004a. Stroke transiently increases subven- tricular zone cell division from asymmetric to symmetric and increases neuronal differentiation in the adult rat. J Neurosci 24: 5810-5815.

Zhang R, Zhang Z, Wang L, Wang Y, Gousev A, Zhang L, Ho KL, Morshead C, Chopp M. 2004b. Activated neural stem cells contribute to stroke-induced neurogenesis and neuroblast migration toward the infarct boundary in adult rats. J Cereb Blood Flow Metab 24: 441-448.

Zhang R, Xue YY, Lu SD, Wang Y, Zhang LM, Huang YL, Signore AP, Chen J, Sun FY. 2006a. Bcl-2 enhances neurogenesis and inhibits apoptosis of newborn neurons in adult rat brain following a transient middle cerebral artery occlusion. Neurobiol Dis 24: 345-356.

Zhang RL, Zhang ZG, Lu M, Wang Y, Yang JJ, Chopp M. 2006b. Reduction of the cell cycle length by decreasing $G_{1}$ phase and cell cycle reentry expand neuronal progenitor cells in the subventricular zone of adult rat after stroke. J Cereb Blood Flow Metab 26: 857-863.

Zhang RL, Zhang ZG, Wang Y, LeTourneau Y, Liu XS, Zhang X, Gregg SR, Wang L, Chopp M. 2007a. Stroke induces ependymal cell transformation into radial glia in the subventricular zone of the adult rodent brain. J Cereb Blood Flow Metab 27: 1201-1212.

Zhang RL, Letourneau Y, Gregg SR, Wang Y, Toh Y, Robin AM, Zhang ZG, Zhang Z, Chopp M. 2007b. Neuroblast division during migration toward the ischemic striatum: A study of dynamic migratory and proliferative characteristics of neuroblasts from the subventricular zone. J Neurosci 27: 3157-3162.

Zhang RL, Chopp M, Gregg SR, Toh Y, Roberts C, LeTourneau Y, Buller B, Jia L, Davarani SPN, Zhang ZG. 2009. Patterns and dynamics of subventricular zone neuroblast migration in the ischemic striatum of the adult mouse. $J$ Cereb Blood Flow Metab 29: 1240-1250.

Zhang C, Chopp M, Cui Y, Wang L, Zhang R, Zhang L, Lu M, Szalad A, Doppler E, Hitzl M, Zhang ZG. 2010. Cerebrolysin enhances neurogenesis in the ischemic brain and improves functional outcome after stroke. J Neurosci Res 88: 3275-3281.

Zhang P, Li J, Liu Y, Chen X, Lu H, Kang Q, Li W, Gao M. 2011. Human embryonic neural stem cell transplantation increases subventricular zone cell proliferation and promotes peri-infarct angiogenesis after focal cerebral ischemia. Neuropathology 31: 384-391.

Zheng J, Zhang P, Li X, Lei S, Li W, He X, Zhang J, Wang N, Qi C, Chen X, et al. 2013. Post-stroke estradiol treatment enhances neurogenesis in the subventricular zone of rats after permanent focal cerebral ischemia. Neuroscience 231: $82-90$

Ziv Y, Ron N, Butovsky O, Landa G, Sudai E, Greenberg N, Cohen H, Kipnis J, Schwartz M. 2006. Immune cells contribute to the maintenance of neurogenesis and spatial learning abilities in adulthood. Nat Neurosci 9: 268-275.

Ziv Y, Finkelstein A, Geffen Y, Kipnis J, Smirnov I, Shpilman S, Vertkin I, Kimron M, Lange A, Hecht T, et al. 2007. A novel immune-based therapy for stroke induces neuroprotection and supports neurogenesis. Stroke 38: $774-$ 782. 


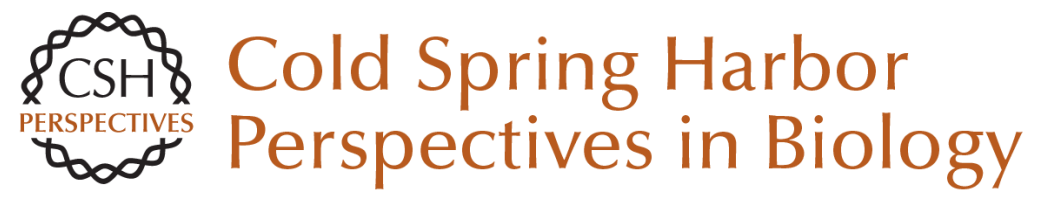

\section{Neurogenesis following Stroke Affecting the Adult Brain}

Olle Lindvall and Zaal Kokaia

Cold Spring Harb Perspect Biol 2015; doi: 10.1101/cshperspect.a019034

Subject Collection Neurogenesis

Adult Neurogenesis and Psychiatric Disorders Eunchai Kang, Zhexing Wen, Hongjun Song, et al.

Neuronal Circuitry Mechanisms Regulating Adult Mammalian Neurogenesis Juan Song, Reid H.J. Olsen, Jiaqi Sun, et al.

Neurogenesis in the Developing and Adult Brain

--Similarities and Key Differences Magdalena Götz, Masato Nakafuku and David Petrik

Genetics and Epigenetics in Adult Neurogenesis Jenny Hsieh and Xinyu Zhao

The Adult Ventricular-Subventricular Zone (V-SVZ) and Olfactory Bulb (OB) Neurogenesis Daniel A. Lim and Arturo Alvarez-Buylla

Diversity of Neural Precursors in the Adult Mammalian Brain Michael A. Bonaguidi, Ryan P. Stadel, Daniel A. Berg, et al.

Detection and Phenotypic Characterization of Adult Neurogenesis H. Georg Kuhn, Amelia J. Eisch, Kirsty Spalding, et al.

Maturation and Functional Integration of New Granule Cells into the Adult Hippocampus Nicolas Toni and Alejandro F. Schinder
Adult Olfactory Bulb Neurogenesis

Pierre-Marie Lledo and Matt Valley

Adult Neurogenesis in Fish Julia Ganz and Michael Brand

In Vitro Models for Neurogenesis Hassan Azari and Brent A. Reynolds

Engineering of Adult Neurogenesis and Gliogenesis

Benedikt Berninger and Sebastian Jessberger

Computational Modeling of Adult Neurogenesis James B. Aimone

Control of Adult Neurogenesis by Short-Range

Morphogenic-Signaling Molecules Youngshik Choe, Samuel J. Pleasure and Helena Mira

Adult Neurogenesis: An Evolutionary Perspective Gerd Kempermann

Epilepsy and Adult Neurogenesis

Sebastian Jessberger and Jack M. Parent

For additional articles in this collection, see http://cshperspectives.cshlp.org/cgi/collection/

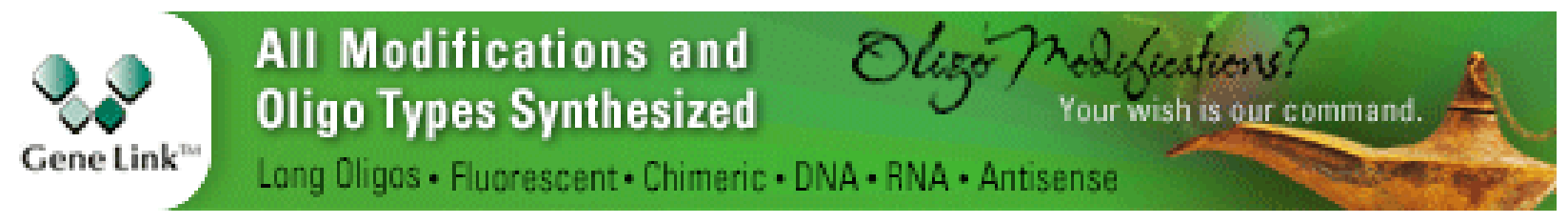

Copyright @ 2015 Cold Spring Harbor Laboratory Press; all rights reserved 